๑๑ Entomologica Fennica. 9 December 2002

\title{
Nanorchestes Topsent and Trouessart, 1890 and Eupodes Koch, 1836 (Acari: Prostigmata) from Vestfjella mountain range, Antarctica
}

\section{Ritva Niemi, Matti Uusitalo \& Petri Lintinen}

Niemi, R., Uusitalo, M. \& Lintinen, P. 2002: Nanorchestes Topsent and Trouessart, 1890 and Eupodes Koch, 1836 (Acari: Prostigmata) from Vestfjella mountain range, Antarctica. — Entomol. Fennica 13: 236-240.

Two terrestrial prostigmatid mites were found from the Audunfjellet nunatak, Vestfjella mountain range, in Dronning Maud Land, Antarctica during the FINNARP expedition in Austral summer 1997/1998. The mites are close to, if not identical to, Nanorchestes bifurcatus Strandtmann, 1967 and Eupodes tottanfjella Strandtmann, 1967, also earlier reported from the area, but identification cannot be verified by using the published descriptions. Samples were also collected from an unnamed nunatak and the Basen nunatak, but these were miteless by chance.

Ritva Niemi, Zoological Museum, University of Turku, FIN-20014 Turku, Finland; E-mail: ritniemi@utu.fi

Matti Uusitalo, Zoological Museum, University of Turku, FIN-20014 Turku, Finland; E-mail: matti.uusitalo@infol.info.tampere.fi

Petri Lintinen, Geological Survey of Finland, FIN-02150 Espoo, Finland; E-mail:petri.lintinen@gsf.fi

Received 6 October 2000, accepted 17 September 2001

\section{Introduction}

During the geological survey of the Finnish Antarctic Research Programme (FINNARP, 1997/ $1998)$ to Vestfjella nunatak range $\left(73-74^{\circ} \mathrm{S}, 13-\right.$ $\left.16^{\circ} \mathrm{W}\right)$, Dronning Maud Land also some soil samples were collected in search for terrestrial mites. Earlier Sømme (1980) and Thor (1996) have reported Eupodes tottanfjella Strandtmann, 1967; Protereunetes maudae Strandtmann, 1967; Tydeus setsukoe Strandtmann, 1967; Tydeus erebus Strandtmann, 1967; Nanorchestes bifurcatus Strandtmann, 1967 and Nanorchestes brekkeristae Strandtmann \& Sømme, 1977 from the nunatak area.

\section{Material and methods}

Soil and moss samples were collected in Vestfjella from three different nunataks (Fig. 1):

- Audunfjellet $\left(73^{\circ} 55^{\prime} 34^{\prime \prime} \mathrm{S} 15^{\circ} 37^{\prime} 48^{\prime \prime} \mathrm{W}\right) 21 \mathrm{exx}(\mathrm{P}$. Lintinen). Moss and soil ca. 1 litre, 2 January 1998.

- Basen $\left(73^{\circ} 01^{\prime} 53^{\prime \prime} \mathrm{S}, 13^{\circ} 21^{\prime} 41^{\prime \prime} \mathrm{W}\right)$ no mites (P. Lintinen). Moss and soil ca. 1 litre, 16 January 1998.

- Basen $\left(73^{\circ} 01^{\prime} 04^{\prime \prime} \mathrm{S}, 13^{\circ} 21^{\prime} 41^{\prime \prime} \mathrm{W}\right)$ no mites (P. Lintinen). Algae from a pond, ca. 0.5 litre, 17 January 1998.

- Unnamed nunatak (73⒌ $\left.3^{\prime} 99^{\prime \prime} \mathrm{S}, 15^{\circ} 46^{\prime} 58^{\prime \prime} \mathrm{W}\right)$ no mites (P. Lintinen). Five km W from Audunfjellet, moss and soil ca. 1 litre, 1 January 1998.

After a three-day extraction process by Berlese funnels and preservation in alcohol during the expedition, the mites were identified in Finland. The specimens were studied by 
Fig. 1. Map of western Dronning Maud Land. The grounding line at the inner edge of the RiiserLarsenisen ice shelf is shown with a solid line, and the outer calving edge with a dashed line. The Finnish research station Aboa is situated on the nunatak Basen. Note that the nunataks are not drawn to scale.

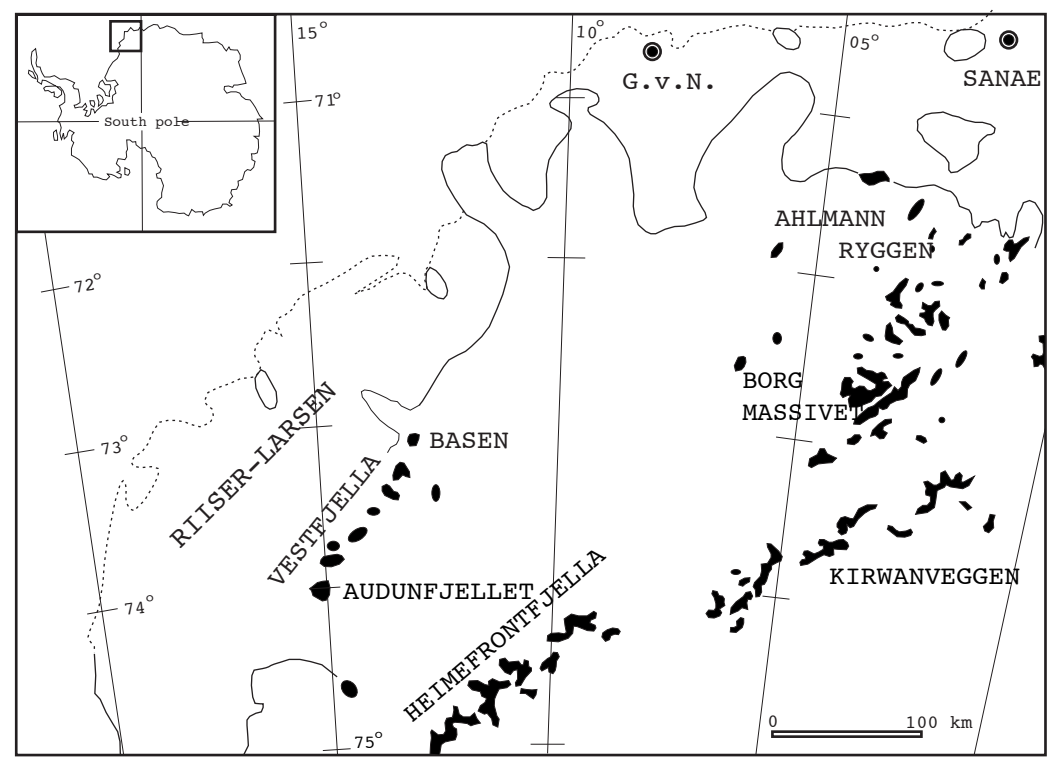

SEM (scanning electron microscope JEOL JSM-5200) after dehydration by CPD (critical point drying method) and coating by gold.

\section{Results and Discussion}

Mitelessness of the samples both from the unnamed nunatak and from the Basen nunatak most probably is a mixture of coincidences: a small number of sample units together with aggregated distribution of mites (e.g. Berthet 1971, Ryan et al. 1989) and unknown distance of the sampling places from snow petrel colonies, where mites exist quite commonly (Sømme 1980, Ryan \& Watkins 1989). Sømme (1980) and Thor (1996) record low numbers of Tydeus erebus, Eupodes tottanfjella and Nanorchestes bifurcatus from the Basen area.

From Audunfjellet nunatak Sømme (1980) reported Eupodes tottanfjella, Tydeus setsukoe, Tydeus erebus and Nanorchestes bifurcatus. Dr. R. W. Strandtmann, the author of the species, identified the mites. Our sample from Audunfjellet includes specimens belonging to two mite genera.

The specimens of genus Nanorchestes (1 larva, 5 nymphs, and 8 adults) correspond well with the fixed specimens of $N$. bifurcatus earlier collected from Audunfjellet by Dr. L. Sømme. There is, however, a noteworthy difference especially in the pattern of prodorsal integument between chelicera (Fig. 2a) if we compare the specimens to the illustration of the redescription of $N$. bifurcatus (figure 1 in Strandtmann [1978]). The redescription, perhaps, only suffers from inadequate drawing technics but the illustrated deutonymph has also lost most of the dorsal setae and a pair of prodorsal setae exp (Fig 2b; for symbols see Kethley [1990]). Differential diagnosis of $N$. bifurcatus (Strandtmann 1967, 1978) is based on the presence of 2-tined dorsal setae. Dorsal setae of our specimens of Nanorchestes have two branches arising from a single axis near its base (Fig. 2a), but 2-tined dorsal setae quite commonly occur on developmental stages of Nanorchestesspecies (Theron \& Ryke 1969, Lindsay 1972, Strandtmann 1982). The form of dorsal setae, at least alone, seem not to be a completely reliable character to identify developmental stages to species. Until now four species of Nanorchestes have been reported from Dronning Maud Land (Ohyama \& Hiruta 1995). The species may inhabit the same sites and adults cannot be separated under field conditions (Sømme 1978).

Genus Eupodes is represented by 2 nymphs and 5 adults in our material. As to characteristics used in differential diagnosis, our specimens of Eupodes have non-swollen femora IV, mediumsized dorsal setae, and a relatively long pair of legs I and IV (Fig. 2c). Of Antarctic members of 

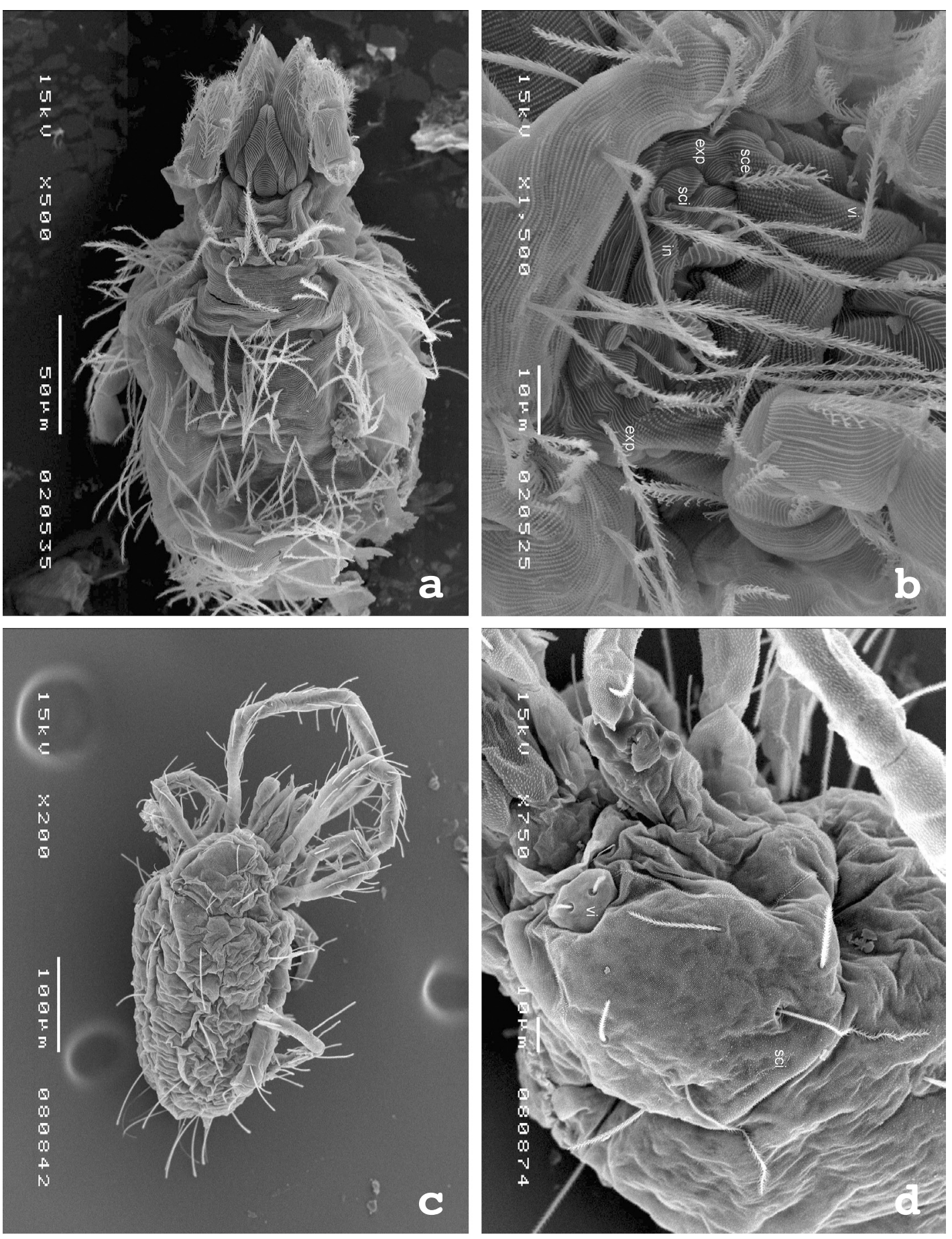

Fig. 2. - a. Nanorchestes nr. bifurcatus; dorsal view (SEM). - b. Nanorchestes nr. bifurcatus; prodorsum (SEM). - c. Eupodes nr. tottanfjella; dorsal view (SEM). — d. Eupodes nr. tottanfjella; prodorsum (SEM). 
the genus also both E. tottanfjella Strandtmann, 1968 and E. angardi Strandtmann \& Sømme, 1977 have non-swollen femora IV, E. wisnesi Strandtmann \& Sømme, 1977 has slightly swollen ones and femora IV are swollen on $E$. wise $i$ Womersley \& Strandtmann, 1966. E. tottanfjella and E. wisnesi are long-legged while $E$. angardi and $E$. wise $i$ have short legs. Dorsal setae are short on $E$. angardi, medium-sized both on E. tottanfjella and on E. wisei, and long on E. wisnesi. There is this variation in the states of the meristic characters between species, but there are also interesting reports of intraspecific variation. Strandtmann and Davies (1972) described two forms of a species (E. crozetensis) which differ not only in respect to the length of the body setae (long and short) but also in body size, and E. angardi is reported to occur in two colour morphs in different habitats (Ryan et al. 1989). Grandjean (1936) and Kethley (1990) emphasize usefulness of the leg solenidiotaxy in delineation of species, but solenidial formula of our species, and according to the descriptions, the formulae of $E$. angardi, E. wisnesi and Eupodes tottanfjella seemed to be identical, even if a solenidion on genu III of $E$. tottanfjella is missing in the text and in the figure, but it is present on fixed specimens from the Sømme Collection.

It is beyond the scope of this paper to revise any part of the Prostigmata fauna of Antarctica and the adjacent islands but inspection of more qualitative characters by modern techniques (e.g. prodorsum in 3-dimension by SEM; Fig. 2d) might help to verify if the mites from Vestfjella, and in general, whether the mite colonies on numerous nunataks of Antarctica really represent good morphospecies or only isolated populations of a species with wider distribution. Strandtmann (1978) proposed Antarctic species to be relicts. Originally Nanorchestes bifurcatus and Eupodes tottanfjella were described by Strandtmann (1967, 1978) from a material collected in the Heimefrontfjella mountain range. About $180 \mathrm{~km}$ of continental ice today separates the type locality and our sampling place (Fig. 1). At the moment, we would rather call our species $N$. cf. bifurcatus and E. cf. tottanfjella. A future revisor may find it useful to have some figures of the mites from this remote, isolated, and only sporadically sampled area for comparison.

Acknowledgements. We thank the expedition leader, Dr. Tapio Ruotoistenmäki, for the possibility to take samples of terrestrial arthropods during the expedition. We are also grateful to Mr. Veikko Rinne (MSc) for his general help. Dr. L. Sømme kindly loaned some slides of Antarctic mites.

\section{References}

Berthet, P. 1971: Mites. — In Phillipson, J. (ed.), Methods of study in quantitative soil ecology: population, production and energy flow: 186-208. Blackwell, Berkshire.

Grandjean, F. 1936: Le genre Pachygnathus Dugès (Alycus Koch) (Acariens), 1re partie. — Bull. Mus. Hist. Nat. Paris, 2e série 8: 398-405.

Kethley, J. 1990: Acarina: Prostigmata (Actinedida). — In: Dindal, D. D. (ed.), Soil Biology Guide: 667-756. John Wiley \& Sons, New York.

Lindsay, K. L. 1972: Nanorchestes antarcticus Strandtmann; a taxonomic description of the instars. - Acarologia 13: 593-606.

Ohyama, Y. \& Hiruta, S. 1995: The terrestrial arthropods of Sør Rondane in eastern Dronning Maud Land, Antarctica, with biogeographical notes. - Polar Biol. 15: 341-347.

Ryan, P. G. \& Watkins, B. P. 1989: The Influence of Physical Factors and Ornithogenic Products on Plant and Arthropod Abundance at an Inland Nunatak Group in Antarctica. - Polar Biol. 10: 151-160.

Ryan, P. G., Watkins, B. P., Lewis Smith R. I., Dastych, H., Eicker, A., Foissner, W., Heatwole, H., Miller, W. R. \& Thompson, G. 1989: Biological survey of Robertskollen, western Dronning Maud Land: area description and preliminary species list. — S. Afr. J. Antarct. Res. 19: 10-20.

Sømme, L. 1978: Notes on the cold-hardiness of prostigmate mites from Vestfjella, Dronning Maud Land. - Norw. J. Entomol. 25: 51-55.

Sømme, L. 1980: Terrestrial arthropods from Vestfjella, Dronning Maud Land (Acari, Collembola), with notes on their taxonomy. - Publ. No. 17 of the Norwegian Antarctic Research Expeditions (1976/77 and 1978/79). Ent. Scand. 11: 61-64.

Strandtmann, R. W. 1967: Terrestrial Prostigmata (Trombidiform mites). — In: Gressit, J. L. (ed.), Entomology of Antarctica, Antarctic Res. Ser. 10: 51-80. American Geophysical Union, Washington D.C.

Strandtmann, R. W. 1978: Redescription of Nanorchestes 
bifurcatus (Acarina: Prostigmata: Nanorchestidae). Pac. Ins. 19: 101-104.

Strandtmann, R. W. 1981: Notes on Nanorchestes. Nanorchestes wilbanksi, n. sp., from Antarctica. - Pac. Ins. 23: 107-111.

Strandtmann, R. W. 1982: Notes on Nanorchestes V. Two new species of Nanorchestes (Acari: Nanorchestidae) from the Antarctic Peninsula and South Atlantic islands. — Pac. Ins. 24: 252-258.

Strandtmann, R. W. \& Davies, L. 1972: Eupodiform mites from Possesion Island, Crozet Islands, with a key to the species of Eupodes (Acarina: Prostigmata). - Pac. Ins. 14: 39-56.

Theron, P. D. \& Ryke, P. A. J. 1969: The family Nanorchestidae Grandjean (Acari: Prostigmata) with descriptions of new species from South African soils. J. Entomol. Soc. Sth. Afr. 32: 31-60.

Thor, G. 1996: Mites collected in Heimefrontfjella and Vestfjella (Dronning Maud Land, Antarctica). - Fauna Norv. Ser. B 43: 69-73. 